\title{
Waspkinins of some Japanese wasps (Vespidae, Hymenoptera)
}

\author{
Terumi Nakajima, ${ }^{1) *}$ Tadashi Yasuhara, ${ }^{*}$ Hisanobu Yoshida, ${ }^{* *}$ \\ Yayoi Ueno, ${ }^{* *}$ Chie Otsuka, ${ }^{* *}$ Masako Hamamoto, ${ }^{* *}$ \\ Mitsuko Nobumori** and Yuko Hirai** \\ *Division of Molecular Biology, Institute for Medical and Dental Engineering, Tokyo Medical \\ and Dental University, 2-3-10, Kanda-Surugadai, Chiyoda-ku, Tokyo 101, Japan \\ **Institute of Pharmaceutical Sciences, Hiroshima University, School of Medicine, \\ 1-2-3, Kasumi-cho, Minami-ku, Hiroshima 734, Japan
}

(Received: July 29, 1983)

Key words: waspkinin, Polistes jadwigae, Polistes chinensis, Vespula lewisii, Vespa analis.

\begin{abstract}
Waspkinins, active peptides analogues to bradykinin in the vespid venom, of some Japanese species were isolated and their structures were determined. The structural differentiation of 9 kinds of the Japanese species in the genera of Polistes, Vespa and Vespula was presented by comparing with their amino sequences.
\end{abstract}

\section{INTRODUGTION}

The vespid venom contains vasoactive peptide analogues to bradykinin. The peptides are called, in general, "waspkinins" as the peptides contract smooth muscle preparations, reduce the blood pressure by i.v. injection and increase the skin permeability similar to bradykinin. The term waspkinin includes the term polisteskinin, vespakinin or vespulakinin which were named for analogoues peptides isolated from the corresponding genera of the vespid insects. Waspkinin is considered as one of the pain producing substance as well as the biogenic amines in the venom. We have investigated such waspkinins of Japanese social wasps and hornets as Polistes rothneyi (Watanabe et al., 1976), Vespa mandarinia (Kishimura et al.,

* 中嶋暉躬, 安原 義: 東京医科歯科大学医用器材 研究所（干101 東京都千代田区神田駿河台 2-310)

**吉田久信, 上野弥生, 大塚智恵, 浜本昌子, 信森 光子, 平井裕子：広島大学医学部総合薬学科 (昰734 広島市南区霞町 1-2-3)

1) To whom correspondence should be addressed.
1976) and Vespa xanthoptera (Yasuhara et al., 1977) and characterized their amino acid sequences. This report deals with the other waspkinins of some Japanese wasps involving Polistes jadwigae, Polistes chinensis, Vespla lewisii and Vespula analis.

\section{Materials and Methods}

\section{Collection of the samples}

Polistes jadwigae was collected at two districts, Takehara, Hiroshima and Ujina, Hiroshima during the period from May 1976 to September 1976. The samples were abbreviated as $\mathrm{pj}_{\mathrm{t}}$ and $\mathrm{pj}_{\mathrm{u}}$ respectively. The other samples used in this study and the preparation of the venom sac extracts were the same as described previously (Nakajima et al., 1983). The numbers of the venom sac employed for the sequential analysis of waspkinin were described in each item of purification.

\section{Assay method}

Oxytocic activity of waspkinins was measured according to the method of Trauschold (1970). The rat uteri were suspended in a 
muscle chamber with de'Jalon's solution and the assays were carried out by comparing the contraction heights with synthetic bradykinin as the standard. The activity was expressed as $\mu \mathrm{g}$ equivalent to synthetic bradykinin. The guinea pig ileum was also used for the bioassay.

Enzymes and enzymatic digestion of peptides

Enzymes used were as follows: $\alpha$-chymotrypsin, Worthington Biochemicals (Millipore Corp.), 83 units/mg protein; trypsin, Worthington Biochemicals (Millipore Corp.), 208 units $/ \mathrm{mg}$ proteins; carboxypeptidase P, Protein Research Foundation, 50 units/mg protein. These enzymes were dissolved in $0.001 \mathrm{~N}$ hydrochloric acid at the concentration of $1 \mathrm{mg} / \mathrm{ml}$ and stored in a freezer $\left(-20^{\circ} \mathrm{G}\right)$. The enzyme solution was diluted to $100 \mu \mathrm{g} / \mathrm{ml}$ with $0.1 \mathrm{M}$ triethylamine bicarbonate $(\mathrm{pH} 8.0)$ before use.

The peptide $(1-10 \mathrm{nmol})$ was dissolved in $10 \mu \mathrm{l}$ of the same solution and $10 \mu \mathrm{l}$ of the diluted enzyme solution was added and incubated at $37^{\circ} \mathrm{C}$ for $4 \mathrm{hr}$ or at room temperature for overnight.

\section{Dansylation and Edman degradation of the peptide}

Dansylation procedure of the peptide and dansy-Edman procedure were performed according to the method of Tamura et al. (1973) and Gray (1967) respectively. The procedure of the Edman degradation was employed according to the method of Edman and Henschen (1975).

\section{Chromatographic procedure}

Gel permeation chromatography was carried out on a Sephadex G-25 or G-15 column with $0.05 \mathrm{M}$ ammonium formate $(\mathrm{pH} 7.0$ ) as the elution solvent. A SE- or SP-Sephadex column was used for ion-exchange chromatography. The sample was dissolved in $1 / 10$ column volume of water, adjusted $\mathrm{pH}$ to 3.0 with dilute formic acid, and centrifuged when the precipitation was formed. The solution was charged on a column and chromatographed as usual with a linear concentration gradient from water to $0.5 \mathrm{~m}$ ammonium formate ( $\mathrm{pH} 7.0$ ).

A solvent system of 1-butanol/pyridine/ water/triethylamine $(10: 1: 10: 0.01)$ was employed for droplet counter current chromatography. The counter current chromatography was performed in the descending fashion using the upper layer as the stationary phase. The sample was dissolved in the upper layer and charged on the first column.

\section{Results}

Isolation and sequence analysis of waspkinin in Polistes chinensis

The crude venom extract from 98 venom sacs was purified as shown in Fig. 1 with SP-Sephadex and Sephadex G-25 chromatography. SP-Sephadex chromatography separated the active principle on the rat uterus contraction into 3 fractions (Pc-1, Pc-2, Pc-3), respectively. The active principle in Pc-1 contracted more potently the guinea pig ileum preparation than the rat uterus and the principle in this fraction was a mixture of histamine and serotonin which was confirmed by high performance liquid chromatography. The active principle in Pc-2 was identified as waspkinin because the fraction lost its activity by the chymotryptic digestion. The activity principle in Pc-3 showed the potent activity on the rat peritoneal mast cells release histamine from the cells and was considered to be mastparanlike peptide. The principle in Pc-2 was further purified by Sephadex G-25 chromatography and the peptide $(216 \mu \mathrm{g})$ equivalent to synthetic bradykinin was isolated.

The peptide was composed of the following amino acids which were determined by an amino acid analyser after usual acid hydrolysis with $6 \mathrm{~N}$ hydrochloric acid at $110^{\circ} \mathrm{C}$ for $24 \mathrm{hr} ; \mathrm{Lys}_{1}, \mathrm{Arg}_{2}, \mathrm{Ser}_{2}, \mathrm{Pro}_{3}, \mathrm{Gly}_{1}$, and $\mathrm{Phe}_{2}$. An N-terminal amino acid was identified as Ser by dancyl method. DansylEdman procedure was performed and the sequence around the $\mathrm{N}$-terminal was deduced as Ser-Lys-Arg-Pro-Pro-Gly-Phe. Chymotrypsin digested the peptide into 3 fragments and 2 of those were identical as dansyl Ser-Pro-Phe and dansyl arginine after the fragments were dansylated and co-chromatographed with the authentic dansyl derivatives. The last one was identified as the $\mathrm{N}$-terminal heptapeptide from its amino acid 


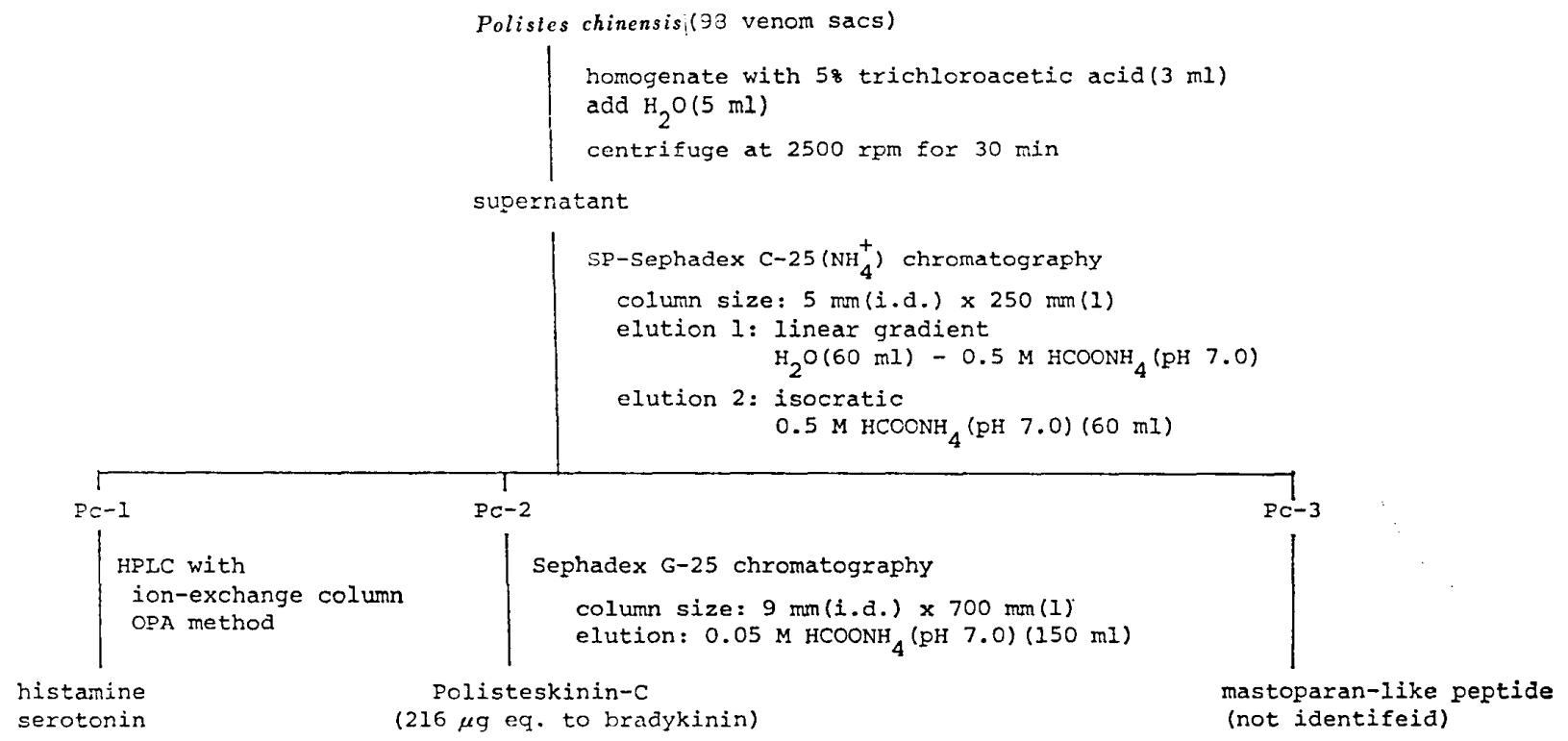

Fig. 1 Purification of polisteskinin-C.

composition.

Accordingly, waspkinin of Polistes chinensis was deduced as Ser-Lys-Bradykinin, for which the name polisteskinin-C was suggested.

Isolation and sequence analysis of waspkinin in Polistes jadwigae

The extract obtained from 178 venom sacs collected at Takehara was similarly separated as shown in Fig. 2. The oxytocic activity was eluted as a single peak in the Sephadex column chromatography. The active fraction was further purified by a Sephadex G-25 column. The active prin- ciple was separated into 2 peaks by this procedure.

The active fraction eluting in $2 / 3$ column volumes contained waspkinin and the fraction in 1.5 column volumes was identified as serotonin by its UV spectrum and thin layer chromatography. The waspkinin was composed of 11 amino acid residues, 2 additional amino acids, arginine and threonine, to those in bradykinin. The stepwise degradation by the Edman procedure gave the amino acid sequence of Arg-Thr-ArgPro-Pro-Gly-Phe from the N-terminal of the peptide. The chymotryptic digestion experi-

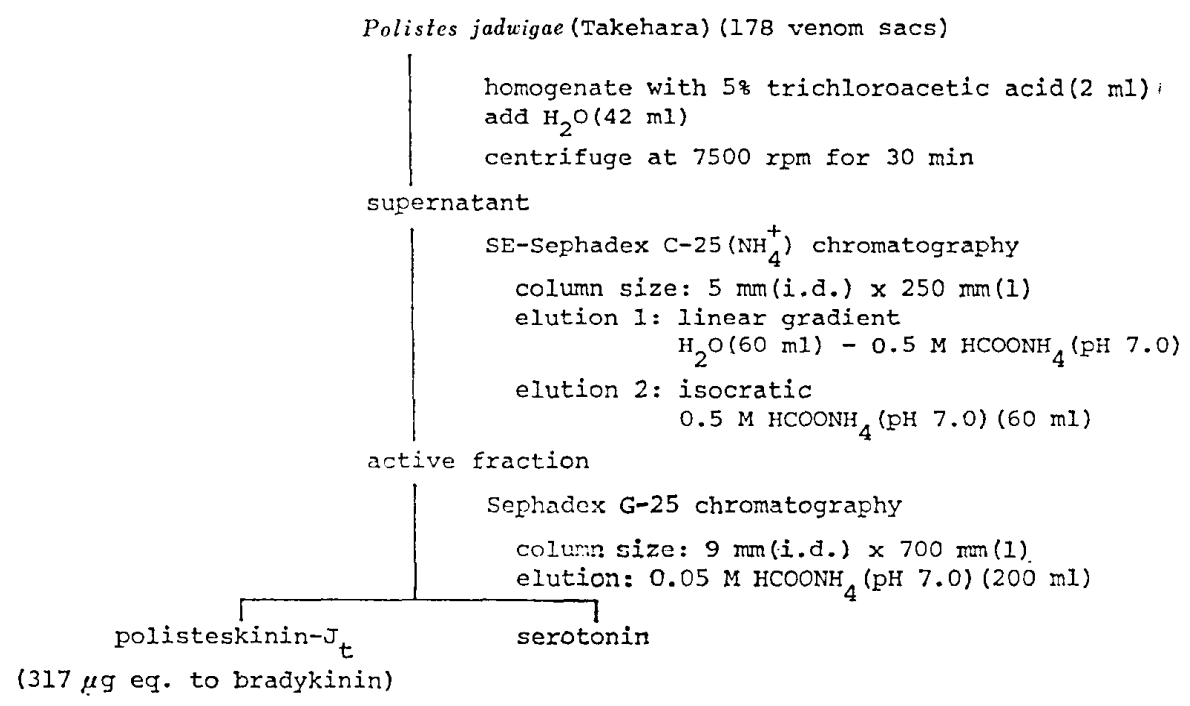

Fig. 2 Purification of polisteskinin- $J_{t}$. 


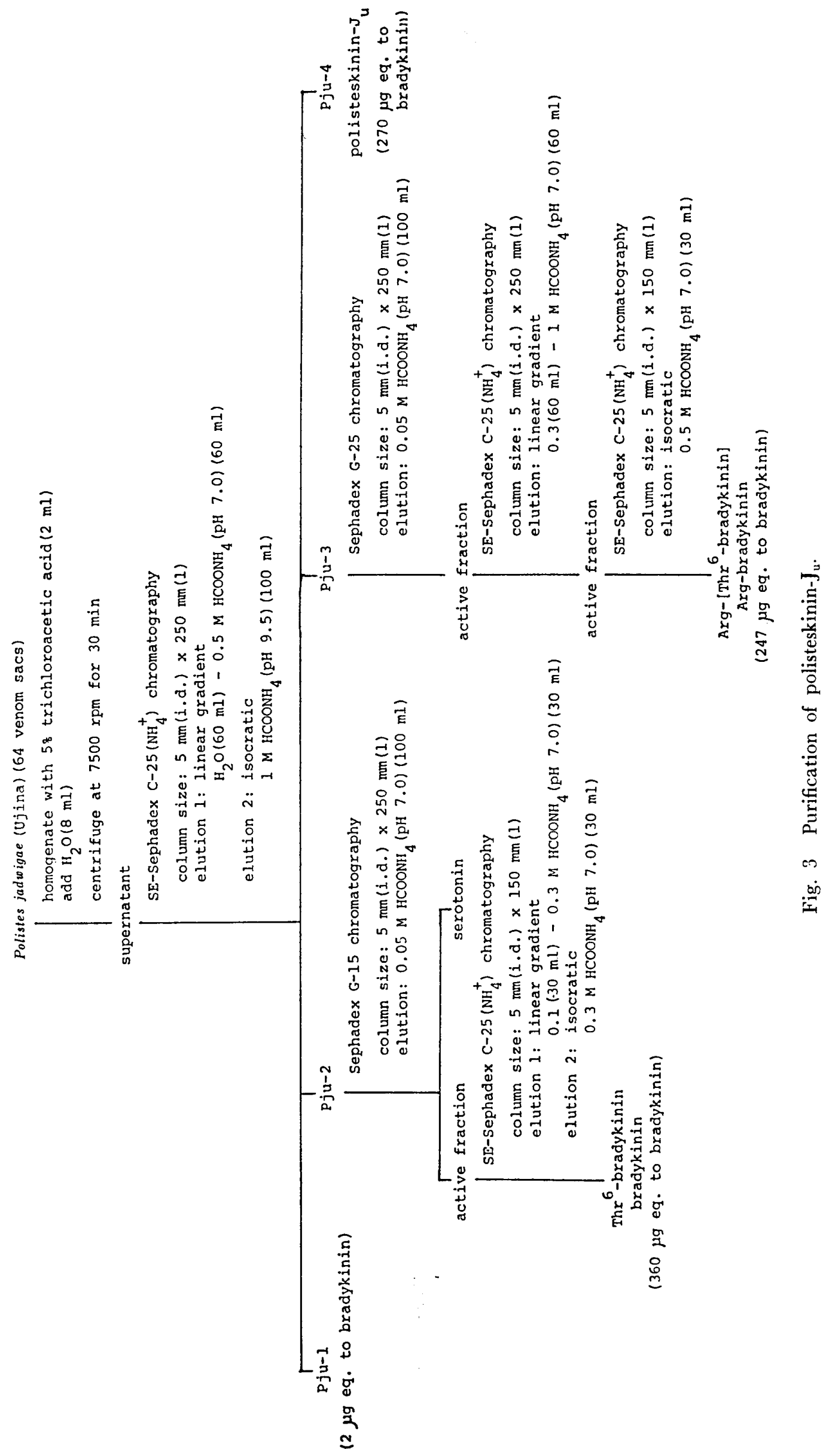


ments similar to that in waspkinin of Polistes chinensis deduced the entire sequence of the peptide as Arg-Thr-bradykinin, for which the name polisteskinin- $\mathrm{J}_{\mathrm{t}}$ was suggested.

The venom sac extract obtained from 64 wasps collected at Ujina, was similarly treated by SE-Sephadex chromatography. The active principle, different from that in the sample collected at Takehara, separated into 4 active fractions $\left(\mathrm{Pj}_{\mathrm{u}}-1, \mathrm{Pj}_{\mathrm{u}}-2, \mathrm{Pj}_{\mathrm{u}}-3\right.$, $\left.\mathrm{Pj}_{\mathrm{u}}-4\right)$. The biological activity for each peak equivalent to synthetic bradykinin was as follows; $\mathrm{Pj}_{\mathrm{u}}-1$ : $2 \mu \mathrm{g}, \mathrm{Pj}_{\mathrm{u}}-2$ : $400 \mu \mathrm{g}, \mathrm{Pj}_{\mathrm{u}}-3$ : $350 \mu \mathrm{g}, \mathrm{Pj}_{\mathrm{u}}-4: 270 \mu \mathrm{g}$, respectively. The active principles in $\mathrm{Pj}_{\mathrm{u}}-2$ and $\mathrm{Pj}_{\mathrm{u}}-3$ were further purified as shown in Fig. 3.

The lyophilized material in $\mathrm{Pj}_{\mathrm{u}}-2$ was successively chromatographed on a Sephadex G-15 column. The principle was separated into 2 peaks. The first peak, eluted at $1 / 3$ column volume, and the second, 2 column volumes. The peaks were identified as waspkinin and serotonin, respectively, as the similar manner to the case of $\mathrm{Pj}_{\mathrm{t}}$. The waspkinin fraction was purified by $\mathrm{SE}$ Sephadex chromatography with 2 steps of the elution system, i.e., 1; gradient elution from 0.1 to $0.3 \mathrm{M}$ ammonium formate $(\mathrm{pH}$ $7.0), 2$; isocratic elution with $0.3 \mathrm{~m}$ ammonium formate $(\mathrm{pH} 7.0)$ respectively. The active principle was eluted at the front of the eluent of $0.3 \mathrm{~m}$ ammonium formate.

The amino acid composition of this peptide was the same as that of bradykinin except that of serine residue. The ratio of serine residue was 0.6 and the peptide con- tained threonine at the ratio of 0.4 . The chymotryptic digestion for $\mathrm{Pj}_{\mathrm{u}}-2$ gave both fragments, Ser-Pro-Phe and Thr-Pro-Phe. Thus the active principle in $\mathrm{Pj}_{\mathrm{u}}-2$ was composed of the microheterogenous peptides, bradykinin and $\mathrm{Thr}^{\mathrm{B}}$-bradykinin.

The active principle in $\mathrm{Pj}_{\mathrm{u}}-3$ was successively purified with Sephadex G-25 and SESephadex chromatography (Fig. 3). The amino acid composition of this principle showed one additional arginine to that of bradykinin, where the same ratio as the case of $\mathrm{Pj}_{\mathrm{u}}-2$ was observed in serine and threonine. The dansyl-Edman degradation was carried out and the sequences of arginyl bradykinin and arginyl $\mathrm{Thr}^{6}$-bradykinin were obtained in $\mathrm{Pj}_{\mathrm{u}}-3$.

In the active principle in $\mathrm{Pj}_{\mathrm{u}}-4$, the amino acid composition was composed of 2 moles of the additional arginine residues to that of bradykinin as well as with the same raito in serine and threonine. The sequence around the $\mathrm{N}$-terminal portion was deduced as Arg-Arg-Arg-Pro-Pro by the dansyl-Edman procedure and the principle consisted of the mixture of arginyl bradykinin and its threonine substitutent, for which the name polisteskinins- $\mathrm{J}_{\mathrm{u}}$ were suggested.

Isolation and sequence analysis of waspkinin in Vespa analis

The venom extract from 50 venom sacs was chromatographed on a column of SPSephadex and Sephadex G-25 successively as shown in Fig. 4. The activity was eluted as a single peak but a broad band in the SE-

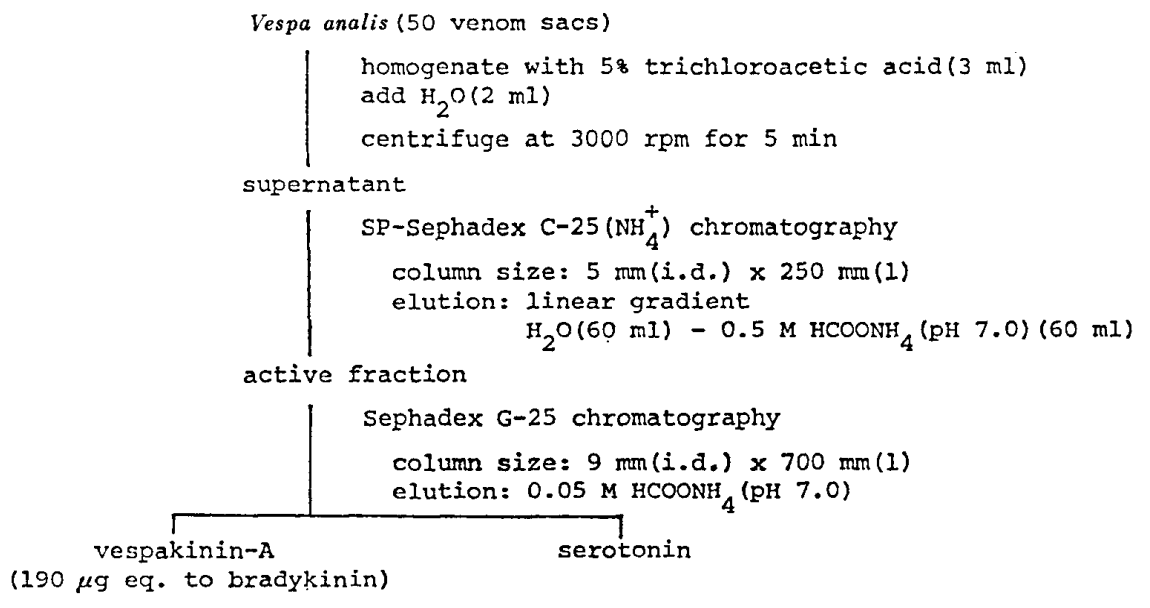

Fig. 4 Purification of vespakinin-A. 
Sephadex chromatography. The most of the activity in this peak was based on the occurrence of serotonin in the venom. Waspkinin was isolated in a same manner as in the case of polisteskinin- $\mathrm{J}_{\mathrm{t}}$ by Sephadex G-25 chromatography and the principle, $190 \mu \mathrm{g}$ equivalent to bradykinin, was obtained. The purified peptide consisted of 12 amino acid residues which contained each $1 \mathrm{~mol}$ of glycine, valine and isoleucine in addition to those in bradykinin. The $\mathrm{N}$-terminal amino acid was identified as glycine by dansyl method. The dansylated peptide was digested by trypsin and 2 triptic fragments, one of which was fluorescent and the other was non-fluorescent, were obtained. The fluorescent fragment derived from the $\mathrm{N}$-terminal position of the peptide showed the same chromatographic behavior as that of dansyl glycyl bradykinin by thin layer chromatography. The non-fluorescent fragment being located at the C-terminal position of the molecule was directly split by the dansylEdman procedure without further isolation from the mixture of the tryptic digest and the sequence of valyl isoleucine was obtained. As the result of these experiments, waspkinin of Vespa analis was deduced as glycyl bradykinyl valyl isoleucine, for which the name
vespakinin-A was suggested.

Isolation and sequence analysis of waspkinin in Vespula lewisii

The waspkinin of Vespla lewisii extracted from 5,000 venom sacs was successively purified by SP-Sephadex, Sephadex G-25 and the droplet counter current chromatography as shown in Fig. 5. The waspkinin was not eluted by the usual concentration gradient from 0 to $0.5 \mathrm{~m}$ ammonium formate $(\mathrm{pH} 7.0$ ) but successive isocratic elution with $1 \mathbf{M}$ ammonium formate $(\mathrm{pH} 7.0)$ in the SPSephadex column chromatography. A Sephadex G-25 column could not purify the waspkinin as the oxytocic active fraction contaminated a large amount of mastparan, a mast cell degranulating peptide (Hirai et al., 1979). The droplet counter current chromatography separated waspkinin from the contamination of mastparan. Waspkinin moved with the lower layer of the solvent system remaining mastparan in the upper layer. The peptide of $3.44 \mu \mathrm{mols}$ calculated from the data of the amino acid analysis was obtained. This waspkinin was a heptadecapeptide composed of the following amino acids; $\mathrm{Lys}_{1}, \mathrm{Arg}_{4}, \mathrm{Thr}_{3}, \mathrm{Ser}_{1}, \mathrm{Pro}_{3}, \mathrm{Gly}_{2}$, $\mathrm{Ala}_{1}$ and $\mathrm{Phe}_{2}$. Waspkinin contained each

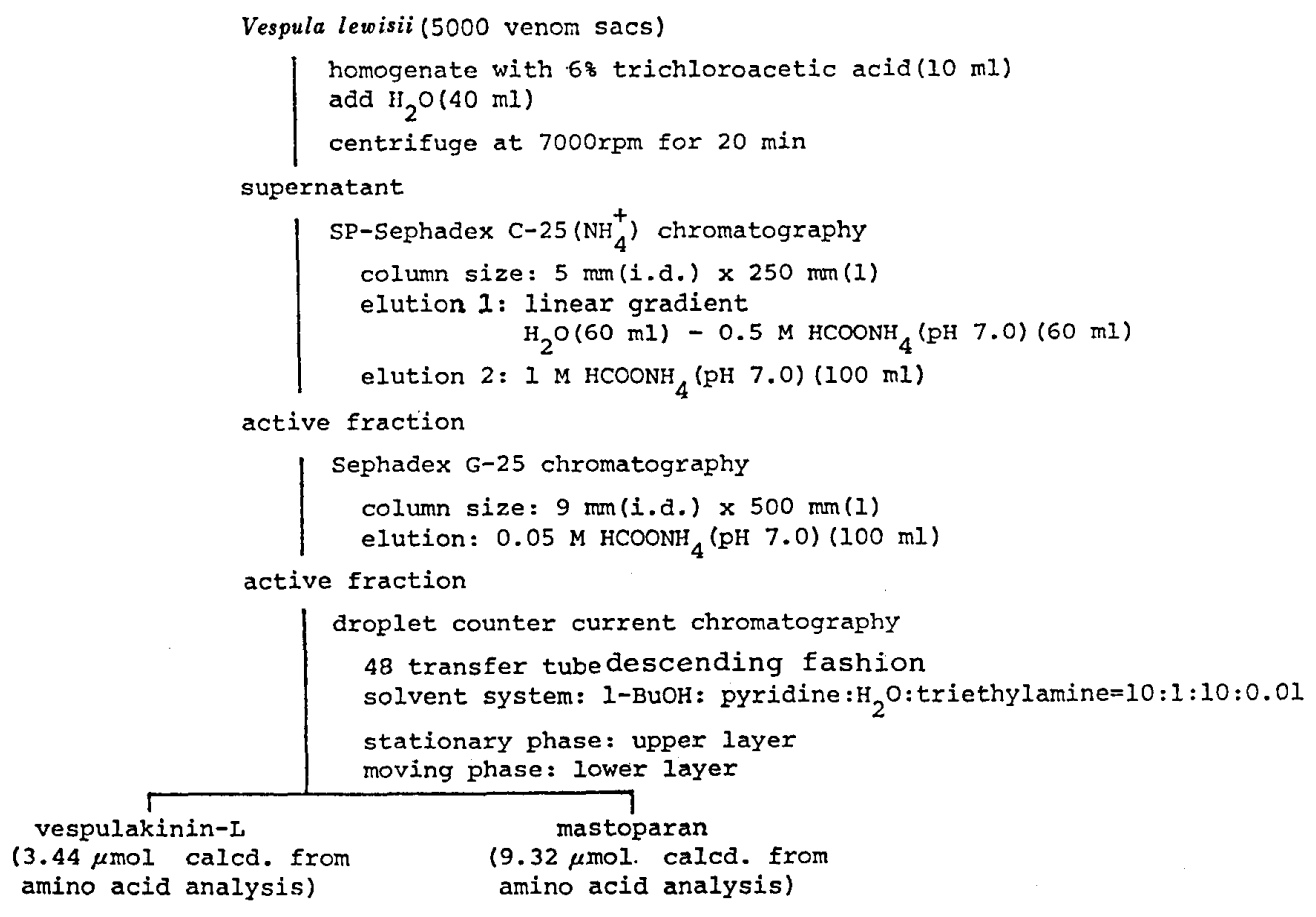

Fig. 5 Purification of vespulakinin-L. 


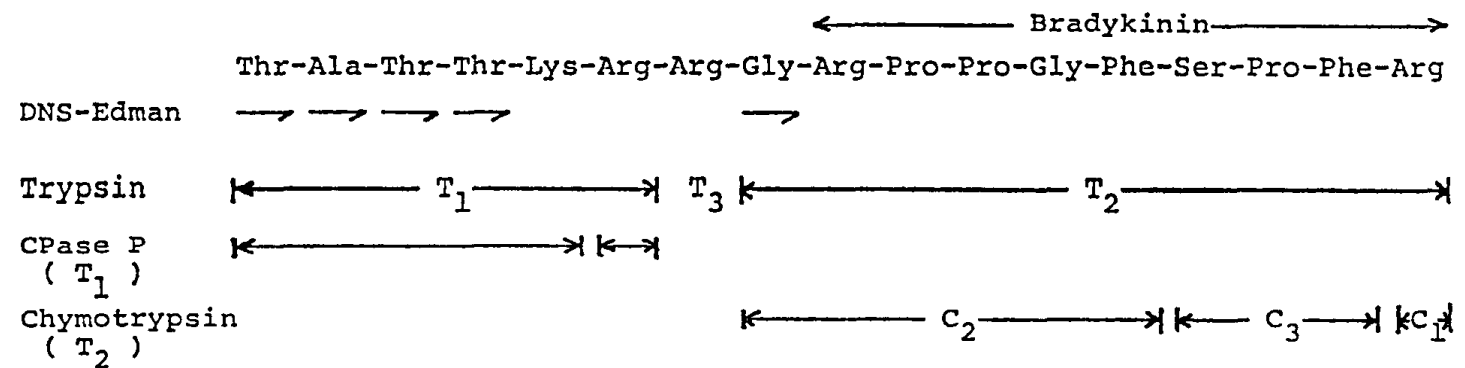

Fig. 6 Sequential analysis of vespulakinin-L.

$1 \mathrm{~mol}$ of galactosamine and galactose in the molecule. The sugar moieties in the peptide was determined by employing the modified method originally described by Honda et al., 1980.*

The dansyl-Edman degradation suggested the N-terminal portion of the peptide as Thr-Ala-Thr-Thr-X-X-X-Gly (X; unidentified). After the 7 steps of the degradation, the remaining part of the peptide coincided with glycyl bradykinin which was confirmed by the similar manner by the chymotrypsin digestion experiment as described previously. The phenylthiohydantoin derivatives liberated in each step of the Edman degradation of the peptide were collected in each step and hydrolysed with $2.5 \mathrm{~m}$ trifluoroacetic acid at $100^{\circ} \mathrm{C}$ for $6 \mathrm{hr}$ and the hydrolysates were submitted to the sugar analysis. The sugar moieties was found to be attached at position 3 of the threonine residue in the peptide.

The intact peptide was dansylated and the dansyl derivative was successively digested by trypsin. Trypsin digested the peptide into 3 fragments $\mathrm{T}-1$ (Fluorescent), T-2 (non-fluorescent), T-3 (non-fluorescent), in which 2 non-fluorescent fragments were identified as glycyl bradykinin and free arginine, respectively, by co-chromatography with the authentic samples. The fluorescent fragment, $T-1$, was digested further by carboxypeptidase $\mathrm{P}$ and liberation of free arginine by this digestion supported the amino acid sequence of the peptide as illustrated in Fig. 6. The name vespulakinin$\mathrm{L}$ was suggested for this peptide.

\footnotetext{
* An improved method for micro-determination of sugars and the sequence analysis of the sugar moieties in the peptide will be reported elsewhere.
}

\section{Discussion}

We examined waspkinin in some Japanese wasps belonging to the subfamilies Polistinae and Vespinae. Table 1 summarizes those waspkinins including the other waspkinins in the Japanese Vespidae. As shown in Table 1 , the peptides isolated from the venom of Polistinae elongate dipeptide containing basic amino acid in the $\mathrm{N}$-terminal of the bradykinin sequence as well as previously reported Polisteskinin-R from the venom of Polistes rothneyi (Watanabe et al., 1976). This differs in a great extent from waspkinin in the American paper wasp as it elongates nonpeptide at the $\mathrm{N}$-terminal of bradykinin (Udenfriend et al., 1967). The presence of the peptides of more than 2 kinds, like in the case of polisteskinins- $\mathrm{R}$ and $\mathrm{J}$, is not clear whether the peptide are matured during the storage in the venom sac or produced by different route of processing of the peptide.

Occurrence of the molecular heterogeneity in waspkinin, as it was seen in the case of polisteskinin- $\mathrm{J}_{\mathrm{t}}$ and $\mathrm{J}_{\mathrm{u}}$, is known in some examples in wild life (Furguson, 1969), but it is noteworthy that, in the case of polisteskinin- $\mathrm{J}_{\mathrm{u}}$, the specimens collected from a colony contained both of the serine and threonine peptide as waspkinin. Whether the workers produce the serine peptide and threonine peptide individually or they produce both of them, are unknown.

The waspkinin in the genus Vespa, in contrast to those in Japanese Polistinae, one amino acid is added to the $\mathrm{N}$-terminal position and also dipeptide with rather hydrophobic amino acid residues enlogates at the C-terminal position of the bradykinin sequence. This is also seen in the other case 


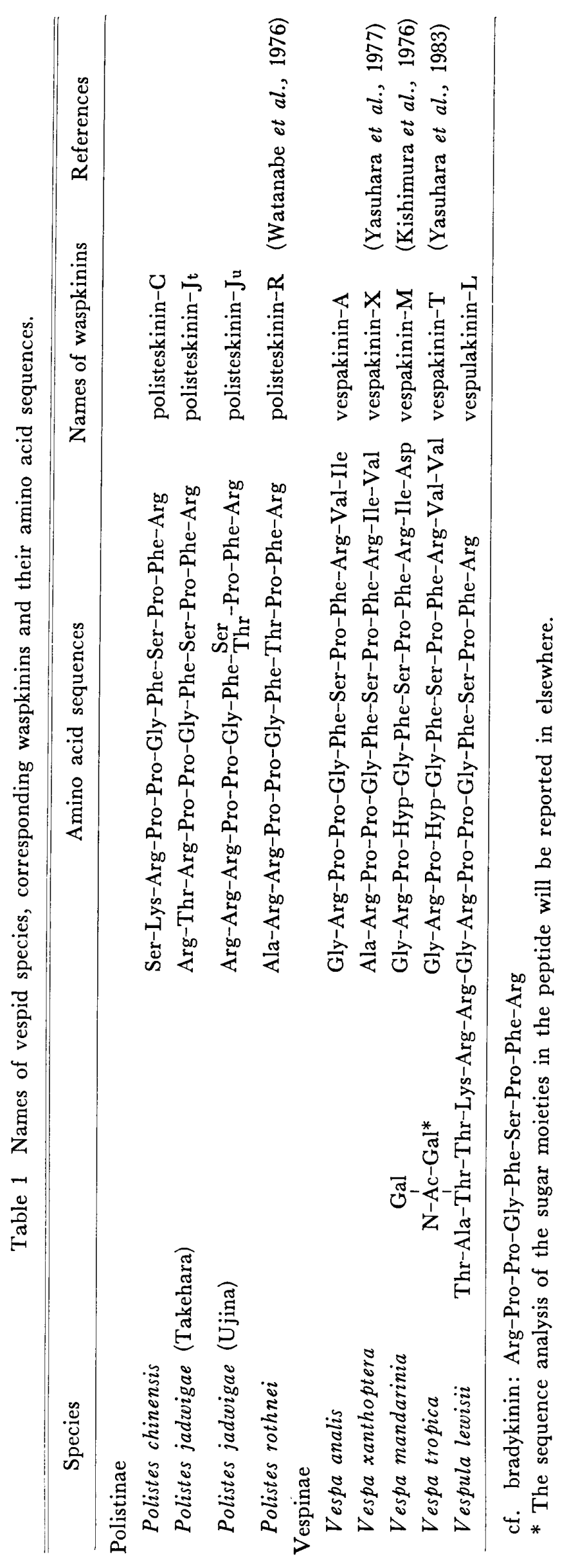


of waspkinins in Japanese hornet.

Vespulakinins, on the other hand, are more different from those waspkinins in the genera Polistes and Vespa with respect to molecular basis of the peptide structure. Vespulakinin$\mathrm{L}$ as well as vespulakinin from Paravespula maculifrons (Yoshida et al., 1976) consists of a larger molecular size heptadecapeptide and, in addition, the molecules contain sugar moieties connected with hydroxyl group in the threonine residue. These peptides are the only examples of carbohydrate containing peptide of small molecular weight including hormones, autacoids or neurotransmitters. Vespulakinin and Vespulakinin-L are quite similar in the amino acid sequence, where a lysine residue at the position 5 of vespulakinin- $\mathrm{L}$ is replaced by arginine in vespulakinin.

The molecular difference of waspkinins between vespid insects arouses the further interest for chemotaxonomical investigation with relation to the other components of the venomous substances.

\section{ACKNOWLEDGEMENT}

We express our deep gratitude to Dr. Ryosuke Ishikawa for his taxonomical identification of our samples. A part of this study was supported by Grant-in-Aid for Scientific Research from the Ministry of Education, Science and Culture of Japan.

\section{References}

Edman, P. and A. Henschen (1975): Sequence determination in molecular biology. In: Biochem. and Biophys., 8 (ed. S. B. Needleman), pp. 232-239, Springer-Verlag, Berlin, Heiderberg, New York.

Furguson, D. R. (1969): The genetic distribution of vasopressin in the peccary (Tyassu angulatus) and worthog (Phacochoerus acthiopicus). Gen. Comp. Endocrinol., 12: 609-613.

Gray, W. R. (1967): Dansyl chloride procedure. Methods Enzymol., 11: 139-151.

Hirai, T., T. Yasuhara, H. Yoshida, T. Nakajima, M. Fujino and C. Kitada (1979): A new mast cell degranulating peptide "mastparan" in the venom of Vespula lewissi. Chem. Pharm. Bull., 27: 1942-1944.

Honda, S., Y. Matsuda, M. Takahashi, K. Kakehi and S. Ganno (1980): Fluorimetric determination of reducing carbohydrates with cyano- acetamide and application to automated analysis of carbohydrates as borate complexes. Anal. Chem., 52: 1079-1082.

Kishimura, H., T. Yasuhara, H. Yoshida and T. Nakajima (1976): Vespakinin-M, a novel bradykinin analogue containing hydroxyproline in the venom of Vespa mandarinia Smith. Chem. Pharm. Bull., 24: 2896-2897.

Nakajima, T., T. Yasuhara, N. Yoshida, Y. Takemoto, S. Shinonaga, R. Kano and H. Yoshida (1983): The pattern analysis of biologically active amines in some Hymenopteran venoms by high performance liquid chromatography. Jap. J. Sanit. Zool., 34: 61-71.

Tamura, Z., T. Nakajima, T. Nakayama, J. J. Pisano and S. Udenfriend (1973): Identification of peptide with 5-dimethylaminonaphthalene sulfonyl chloride. Anal. Biochem., 52 : 595-606.

Trauschold, I. (1970): Assay methods in the kinin systems. In: Handbook of Expermtl. Pharmacol., 25 (ed. Erdös, E. G.), pp. 52-81, Springer-Verlag, Berlin, Hiderberg, New York.

Udenfriend, S., T. Nakajima and J. J. Pisano (1967): Structure of the major kinin in wasp (Polistes) venom. Proc. 7th Intnatl. cong. Biochem., VIII-4, 501.

Watanabe, M., T. Yasuhara and T. Nakajima (1976): Occurrence of $\mathrm{Thr}^{6}$-bradykinin and its analogus peptide in the venom of Polistes rothneyi iwatai V. der Vecht. In: Animal, Plant and Microbial Toxins (eds., Ohsaka, A., K. Hyashi and Y. Sawai), pp. 105-112, Plenum Press, New York, London.

Yasuhara, T., H. Yoshida and T. Nakajima (1977): Chemical investigation of the hornet (Vespa xanthoptera Cameron) venom. The structure of a new bradykinin analogue "vespakinin-X”. Chem. Pharm. Bull., 25: 935-941.

Yasuhara, T., T. Nakajima and V. Erspamer (1983): Isolation and sequence analysis of active peptides in the picomolar level. In: Peptide Chemistry (1982) (ed. S. Sakakibara), pp. 213-218, Protein Res. Foundation, Osaka.

Yoshida, H., R. G. Geller and J. J. Pisano (1976) : Vespulakinins: New carbohydrate containing bradykinin derivatives. Biochem., 15: 61-64.

\section{摘 要 \\ 日本産スズメバチ科のハチ毒キニン}

本邦産スズメバチ科の八チ毒キニンを単離し，その 構造を解析した。すでにわれわれが構造を解析したも のも含め，9種類の本邦産八チ毒キニンのアミノ酸配 列から Polistes 属, Vespa 属およびVespula 属の八 チ毒キニンの構造上の特徴を提示した. 